\title{
EVALUASI IMPLEMENTASI ALGORITMA IMPROVED K-NEAREST NEIGHBOR PADA KATEGORISASI LIRIK LAGU BAHASA INDONESIA MENURUT USIA
}

\author{
Faisal Rahutomo', Imam Fahrur Rozi², Pangestu Nur Mirzha ${ }^{3}$ \\ 1,2,3 Teknik Informatika, Politeknik Negeri Malang \\ ${ }^{1}$ faisalrahutomo@polinema.ac.id, ${ }^{2}$ imam.rozi@ polinema.ac.id, ${ }^{3}$ pangestunurmirzha@gmail.com
}

\begin{abstract}
Abstrak
Pesatnya perkembangan teknologi mempercepat proses penyebaran lagu di Indonesia. Namun lagu yang beredar belum disertai dengan label batasan usia pendengar berdasarkan liriknya, seperti label usia pada film. Hal tersebut tentu membuat masyarakat kesulitan untuk memilih lagu yang sesuai usianya, sehingga masyarakat bebas menikmati berbagai lagu dan akan berdampak buruk terhadap perkembangan mental masyarakat di bawah umur. Oleh karena itu, dengan membuatkan sebuah sistem yang dapat menyaring sebuah lagu berdasarkan latar belakang usia sehingga lagu akan mempunyai sebuah label. Penelitian ini menggunakan metode Improved K-Nearest Neighbor yaitu untuk mengklasifikasikan sebuah lagu berdasarkan usianya. Proses dimulai dari melakukan preprocessing data, perhitungan TF.IDF, perhitungan cosine similarity, dan melakukan klasifikasi dengan metode Improved K-Nearest Neighbor. Berdasarkan pengujian yang sudah peneliti lakukan tingkat akurasi dari pengembangan rekomendasi lirik lagu menggunakan Improved K-Nearest Neighbor mendapatkan hasil terbaik yakni akurasi sebesar $51 \%$, precision sebesar $100 \%$, recall sebesar $100 \%$, dan $f$-measure sebesar $100 \%$ untuk masing-masing kategori.
\end{abstract}

Kata kunci : Klasifikasi, Lirik lagu, Improved K-Nearest Neighbor

\section{Pendahuluan}

Semakin berkembangnya zaman berdampak pada sebagian besar aspek kehidupan masyarakat, termasuk dalam proses persebaran lagu. Dengan adanya terknologi yang canggih seperti smartphone dan di dukung dengan kemudahan dalam mengakses internet yang begitu baik, seluruh elemen masyarakat khususnya di Indonesia dapat mengakses begitu banyaknya lagu pada layanan digital yang menyediakan list lagu lokal maupun mancanegara. Hal ini memberikan dampak positif terhadap industri lagu yang dimana orang-orang akan semakin kreatif dalam memproduksi lagu serta memberikan pengenalan masyarakat terhadap lagu-lagu, baik lagu yang sudah beredar maupun lagu yang baru beredar.

Dalam proses penyebaran dan pengenalan lagu yang begitu cepat di Indonesia, masih kurang diimbangi dengan sistem yang dapat melakukan penyaringan atau klasifikasi pada lagu itu sendiri, khususnya dalam mengkategorikan lagu berdasarkan usia. Proses penyaringan lagu yang tidak maksimal, menyebabkan masyarakat akan kebingungan akan memilih lagu mana yang cocok dengan latar belakang usia mereka.

Berdasarkan pemaparan di atas yang akan dilakukan adalah membangun sistem yang dapat mengkategorikan lirik lagu menurut usia secara otomatis menggunakan algoritma Improved $K$ Nearest Neighbor dan menggunakan cross validation untuk pembentukan data training-nya. Dengan adanya sistem klasifikasi ini, diharapkan dapat mengetahui klasifikasi dari lirik lagu sehingga masyarakat dapat melakukan penyaringan terhadap lirik lagu yang beredar di masyarakat.

\section{Landasan Teori}

\subsection{Text Mining}

Text mining merupakan proses untuk melakukan penambangan data dari dokumen atau data-data yang tidak terstruktur. Text mining berusaha untuk menghasilkan informasi yang tersirat secara implisit atas informasi yang dengan otomatis diekstak dari dokumen (Feldman, 2007). Text mining memiliki tujuan untuk mendapatkan hasil berupa informasi yang berguna dari kumpulan-kumpulan dokumen, adapun sumber data yang digunakan untuk melakukan text mining adalah berupa data yang tidak terstruktur atau semi terstruktur.

\subsection{Text Preprocessing}

Pada text mining, struktur data yang baik dapat mempermudah proses komputerisasi secara otomatis. Maka dari itu, diperlukan beberapa tahapan untuk pengubahan dari informasi yang terstrukturnya sembarang menjadi lebih terstruktur sesuai dengan kebutuhan. Tahapan awal dari text mining adalah text preprocessing yang bertujuan untuk mempersiapkan 
teks menjadi data yang terstruktur dan dapat diproses pada tahapan berikutnya. Secara umum tahapantahapan dari text preprocessing adalah Case Folding, Tokenizing, Filtering, dan Stemming. Case Folding adalah mengubah seluruh huruf dari 'a' sampai dengan ' $z$ ' dalam dokumen menjadi huruf kecil. Tokenizing adalah pemotongan string input berdasarkan tiap kata yang menyusunnya. Filtering adalah mengambil kata-kata penting dari hasil tokenizing berdasarkan stopword kata. Stemming adalah tahap mencari root kata dari tiap kata hasil filtering.

\subsection{Pembobotan}

Pembobotan atau term weighting merupakan proses mendapatkan nilai dari term yang berhasil diekstrak dari proses sebelumnya.

Term Frequency (TF) adalah frekuensi kemunculan term (kata) dalam suatu dokumen, frekuensi untuk setiap term dapat bervariasi oleh karena itu frekuensi kemunculan term menjadi atribut penting untuk membedakan dokumen satu sama lain sedangkan Wtf ialah suatu proses untuk melakukan perhitungan bobot untuk setiap term (Nurul M et al, 2018). Untuk menentukan nilai $T F$ dan Wtf ditunjukkan pada persamaan berikut:

$$
W t f t d=\left\{\begin{array}{l}
1 \\
0
\end{array}+\log \mathrm{tftd}, \mathrm{tftd} \geq 1\right.
$$

Keterangan:

Wtftd = hasil dari pembobotan $t f t d$

Tftd = frekuensi kemunculan $\mathrm{t}$ pada dokumen $\mathrm{d}$

Document Frequency (DF) adalah jumlah dokumen yang memiliki term (kata) t dan Inverse Document Frequency adalah jumlah dari dokumen yang memiliki term (kata) t yang dicari dalam kumpulan dokumen yang ada (Nurul M et al, 2018). Untuk melakukan perhitungan $I D F$ ditunjukkan pada persamaan berikut:

$$
i d f t=\log \frac{N}{d f t}
$$

Keterangan:

$$
\begin{array}{ll}
I d f t & =\text { Hasil dari invers } d f t \\
d f t & =\text { Jumlah dokumen yang memiliki } \mathrm{t} \\
\mathrm{N} & =\text { Banyak dokumen yang ada }
\end{array}
$$

Pembobotan TF.IDF (Wtd) adalah proses untuk melakukan penggabungan bobot pada tiap term dalam setiap dokumen. Untuk menghitung pembobotan TF.IDF dapat dilakukan dengan melakukan perkalian $T F$ dan IDF (Nurul M et al, 2018). Untuk melakukan perhitungan TF.IDF dapat dilakukan dengan persamaan berikut:

$$
W t d=W t f t d * i d f t
$$

\subsection{Cosine Similarity}

Cosine similarity digunakan untuk menghitung similaritas antara dua dokumen.Penentuan kesesuaian dokumen dengan query dipandang sebagai pengukuran (similarity measure) antara vector dokumen (D) dengan vector query (Q). Semakin sama suatu vector dengan dokumen dapat dipandang semakin sesuai dengan query (Nurfarida D.R et al, 2019). Perhitungan cosine similarity dapat dilakukan dengan persamaan sebagai berikut:

$$
\cos \operatorname{Sim}(X, d j)=\frac{\sum_{i=1}^{m} x i . d j i}{\sqrt{\left(\sum_{t}^{n}=1 x i\right)^{2} \cdot \sqrt{\left(\sum_{t}^{m}=1 d j i\right)^{2}}}}
$$

\subsection{Improved K-Nearest Neighbor}

Metode Improved $K-N N$ adalah metode yang dikembangkan dari metode $K-N N$, dimana perbedaannya terdapat pada penentuan nilai $\mathrm{k}$. Pada $K-N N$ menentukan nilai k harus sesuai dan tepat agar bisa mendapatkan nilai akurasi yang tinggi dalam melakukan klasifikasi dokumen.

Pada Improved $K-N N$ dilakukan perubahan dalam menentukan nilai $\mathrm{k}$, yang mana pada Improved K-NN setiap kategorinya memiliki nilai $\mathrm{k}$ yang berbeda sesuai dengan besar atau kecilnya dokumen latih yang dimiliki oleh setiap kategori, sehingga saat nilai k semakin tinggi tidak akan mempengaruhi pada kategori dengan jumlah dokumen latih yang besar (Nurul M et al, 2018).

Setelah menghitung nilai cosine similarity maka hasil perhitungannya akan diurutkan secara menurun untuk setiap kategori. Setelah itu dilakukan penentuan nillai $\mathrm{k}$, selanjutnya akan dilakukan perhitungan untuk mendapatkan nilai $\mathrm{k}$ baru (n), menentukan nilai $\mathrm{k}$ baru(n) dapat dihitung menggunakan persaman berikut (Herdiawan, 2015):

$$
n=\frac{k * N(\mathrm{~cm})}{\operatorname{Maks}[N(\mathrm{~cm})] j=1 . . N c}
$$

Keterangan:

$\begin{array}{ll}n & =\text { Nilai k baru } \\ k & =\text { Nilai k yang ditetapkan } \\ \text { Maks }[N(\mathrm{~cm})] j=1 . . N c & \text { Banyak dokumen latih } \\ & \text { terbanyak pada semua } \\ & \text { kategori }\end{array}$

Selanjutnya dilakukan perhitungan peluang dari dokumen uji $\mathrm{X}$ termasuk dengan dokumen latih dj sebanyak nilai $\mathrm{n}$ tetangga untuk setiap kategori pada dokumen X pada dokumen latih dj sebanyak nilai $\mathrm{n}$ tetangga untuk training set. Persamaan berikut dapat digunakan untuk menghitung peluang dari dokumen uji X pada kategori m (Baoli, Shiwen, dan Qin, 2003).

$\frac{\sum d j \in t o p \_n \_k N N(\mathrm{~cm}) \operatorname{sim}(x, d j) y(d j, \mathrm{~cm})}{\sum d j \in t o p \_n}$ 
Keterangan:

$\operatorname{Sim}(x, d j)$

top_n_kNN

$Y(d j, c m)$
$P(x, \mathrm{~cm})$

$=$ Probabilitas dokumen $\mathrm{X}$

$=$ Kemiripan antara dokumen $\mathrm{X}$ dengan dokumen latih

$=$ Nilai $\mathrm{n}$ terbaik tetangga

$=$ Fungsi atribut yang memenuhi dari salah satu kategori, apabila dokumen latih dj masuk dalam kategori $\mathrm{cm}$ maka akan bernilai 1 , dan sebaliknya jika tidak maka akan bernilai 0 .

\section{Metodologi Penelitian}

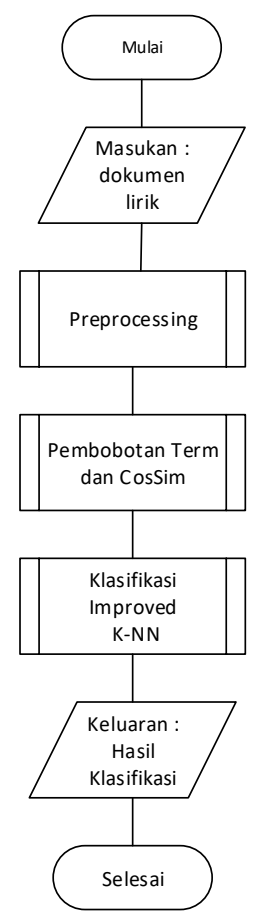

Gambar 1. Diagram Alir Sistem

Berdasarkan Gambar 1 di atas terdapat beberapa tahapan yang dilalui dalam melakukan penelitian ini, yakni diawali dengan mencari literatur yang sesuai, mengumpulkan data, melakukan analisis kebutuhan, merancang sistem, implementasi sistem, melakukan pengujian, menganalisis serta penarikan kesimpulan.

Tujuan sistem yang akan dikembangkan ialah agar mengklasifikasikan lirik lagu berbahasa Indonesia berdasarkan usia ke dalam beberapa kategori. Proses untuk mengklasifikasikan tersebut dimulai dengan memberikan input berupa dokumen, kemudian tahap selanjutnya ialah preprocessing, yakni proses yang berguna untuk memperbaiki atau menyiapkan dokumen yang di inputkan. Lalu dilakukan pembobotan dan perhitungan cosine similarity, setelah itu dilakukan proses klasifikasi menggunakan metode Improved $K-N N$. Setelah semua tahap dilakukan maka akan didapatkan hasil kategori atas data uji, dimana nilai yang terbesar dari hasil perhitungan probabilitas merupakan kategori untuk data uji.

\section{Perancangan dan Implementasi}

\subsection{Pengumpulan Dataset}

Metode pengumpulan dataset digunakan untuk mengumpulkan data-data pendukung yang dibutuhkan dalam proses pembuatan aplikasi. Beberapa cara yang bisa digunakan adalah melalui studi literatur, yaitu dengan mengumpulkan dan mempelajari beberapa referensi dari berbagai sumber yang berkaitan dengan penelitian yang digunakan. Untuk keperluan data penelitian yang akan digunakan, yaitu dengan menggunakan data penelitian sebelumnya yaitu dengan judul "Implementation of Naïve Bayes Classifier Algorithm to Categorize Indonesian Song Lyrics Based on Age", dengan sejumlah 400 lirik lagu berbahasa Indonesia. Dataset yang didapat berupa file xlxs yang kemudian setiap data lirik dan labelnya disimpan ke dalam database (Faisal R, Thirafi, M.Fadli, 2019).

\subsection{Implementasi Sistem}

Implementasi sistem klasifikasi lirik lagu terdapat beberapa langkah yaitu preprocessing, perhitungan TF.IDF, perhitungan cosine similarity, serta hasil dari metode improved k-nearest neighbor. Berikut adalah tampilan implementasi sistem klasifikasi lirik lagu menggunakan metode improved k-nearest neighbor.

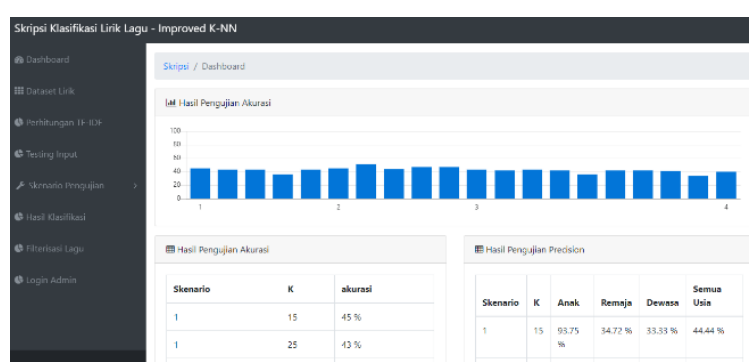

Gambar 2. Halaman Depan/Dashboard

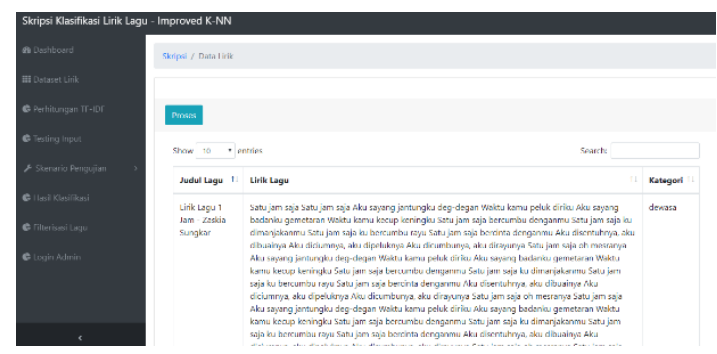

Gambar 3. Data Lirik Lagu 


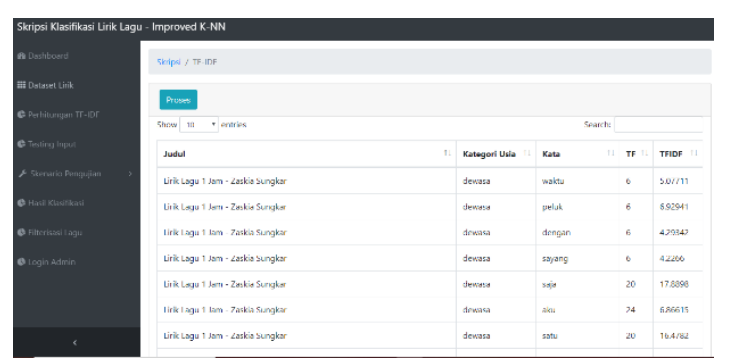

Gambar 4. Data TF.IDF Kata
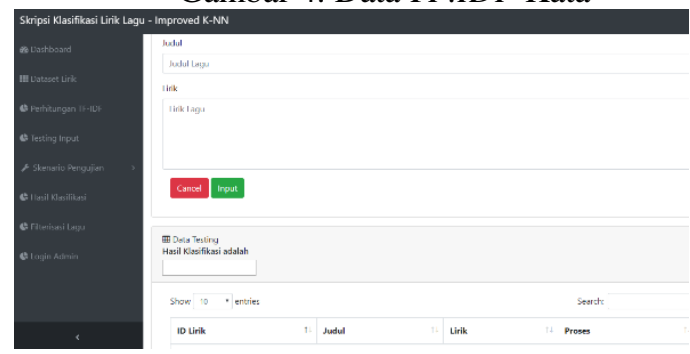

Gambar 5. Testing Input

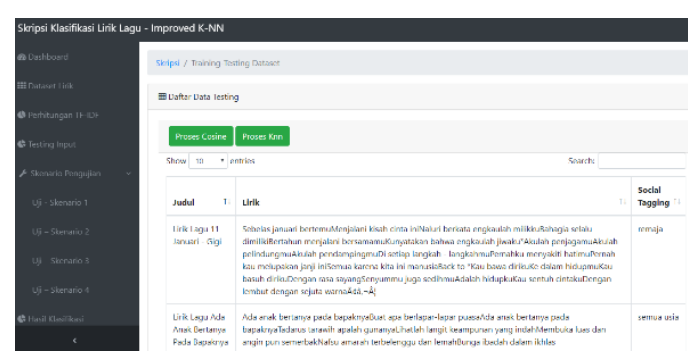

Gambar 6. Skenario Pengujian

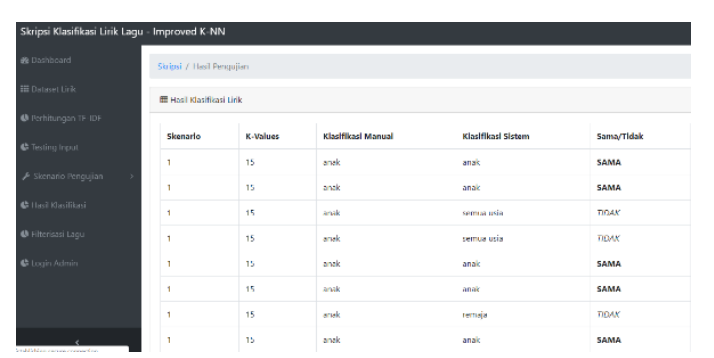

Gambar 7. Hasil Klasifikasi

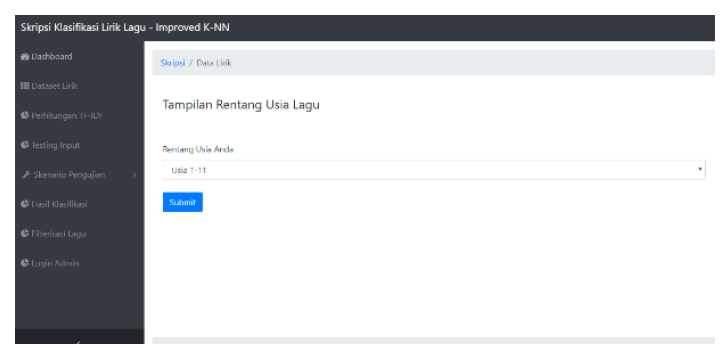

Gambar 8. Filterisasi Lagu

Gambar 2 merupakan halaman untuk menampilkan hasil pengujian sistem. Pada halaman ini menampilkan data hasil pengujian yang berupa akurasi, recall, precision, dan $f$-measure berdasarkan skenario yang telah diinputkan.

Gambar 3 merupakan halaman untuk menampilkan hasil import data dari dataset yang berupa file Microsoft Excel (.xls / .xlsx). Pada halaman ini menampilkan data lagu yang berupa judul lagu, lirik lagu, dan kategori lagu.
Gambar 4 merupakan halaman untuk melakukan TF.IDF terhadap data lirik lagu, serta pada halaman ini menampilkan hasil dari perhitungan TF.IDF terhadap data lirik lagu. Pada halaman ini juga menampilkan lirik lagu, kategori lagu, kata, serta perhitungan $T F$, dan perhitungan $T F . I D F$.

Gambar 5 merupakan halaman untuk melakukan testing diluar dataset. Pada halaman ini user dapat menginputkan lirik dan lirik tersebut akan diproses untuk mendapatkan hasil dari klasifikasinya.

Gambar 6 merupakan halaman untuk melakukan perhitungan cosine similarity dan metode Improved K-Nearest neighbor, serta pada halaman ini menampilkan data untuk dilakukan training dan testing.

Gambar 7 merupakan halaman untuk menampilkan hasil dari klasifikasi lirik lagu yang telah dilakukan pengujian berdasarkan skenario pengujian. Pada halaman ini menampilkan data klasifikasi yang berupa skenario, k, klasifikasi manual, klasifikasi sistem, dan sama atau tidak dari klasifikasi lirik lagu.

Gambar 8 merupakan halaman untuk menampilkan lagu berdasarkan rentang usia. Pada halaman ini user akan menginputkan rentang usianya dan kemudian sistem akan menampilkan lagu yang terkait dengan rentang usianya.

\section{Pengujian Sistem}

Untuk mengetahui pengaruh dan banyak dokumen latih serta k pada keberhasilan sistem, maka dilakukan tahap pengujian menggunakan skenarioskenario pengujian (Nurul M, 2018). Masing-masing skenario memiliki junlah data latih yang sama dimana data latih sebanyak 300 dokumen dan 100 untuk dokumen data uji. Serta memiliki nilai $\mathrm{k}$ yang dilakukan sama sebanyak 5 kali literasi dengan ketentuan nilai $\mathrm{k} 3,5,15,25,35$, dan 45 . Menggunakan k yang semakin tinggi dan berbedabeda nilainya diharapkan agar mendapatkan nilai keakuratan yang tinggi ketika mengklasifikasikan hasil pengujian. Tabel 1 menunjukkan pembagian pengujian yang dibangun.

Tabel 1. Skenario Data Training
\begin{tabular}{|c|c|c|c|c|c|}
\hline $\begin{array}{c}\text { Datas } \\
\text { et }\end{array}$ & \multicolumn{6}{|c|}{ Data Latih } \\
\cline { 2 - 6 } & $\begin{array}{c}\text { Ana } \\
\mathrm{k}\end{array}$ & $\begin{array}{c}\text { Remaj } \\
\mathrm{a}\end{array}$ & $\begin{array}{c}\text { Dewas } \\
\mathrm{a}\end{array}$ & $\begin{array}{c}\text { Semu } \\
\mathrm{a} \\
\text { Usia }\end{array}$ & $\begin{array}{c}\text { Jumla } \\
\mathrm{h}\end{array}$ \\
\hline 1 & 25 & 25 & 25 & 25 & 100 \\
\hline 2 & 25 & 25 & 25 & 25 & 100 \\
\hline 3 & 25 & 25 & 25 & 25 & 100 \\
\hline 4 & 25 & 25 & 25 & 25 & 100 \\
\hline
\end{tabular}


Tabel 2. Skenario Pengujian

\begin{tabular}{|l|l|l|l|l|}
\hline Skenario & Training & Jumlah & Testing & Jumlah \\
\hline 1 & $1,2,3$ & 300 & 4 & 100 \\
\hline 2 & $1,2,4$ & 300 & 3 & 100 \\
\hline 3 & $1,3,4$ & 300 & 2 & 100 \\
\hline 4 & $2,3,4$ & 300 & 1 & 100 \\
\hline
\end{tabular}

Pada tabel 2 menunjukkan pembagian skenario pengujian data menggunakan cross validation $k$-fold. Dengan menggunakan $4 k$-fold sebagai pengujian sistem, maka pembagian skenario pengujian dibagi menjadi 4 tahap. Dimana untuk data training dan data testing nya menggunakan pembagian dataset dari tabel 1.

\subsection{Skenario 1}

Pengujian pada skenario 1 dilakukan dengan menggunakan data latih sejumlah 300 dokumen dari pembagian dataset 1,2 , dan 3 dimana pada setiap kategori memiliki jumlah data latih yang sama yaitu sebesar 75, serta menggunakan id dokumen lirik dari id 75 hingga id lirik 100 pada data uji.

Tabel 3. Hasil Precision Skenario 1

\begin{tabular}{|c|c|c|l|l|}
\hline \multicolumn{5}{|c|}{ Precision } \\
\hline $\mathrm{k}$ & Anak & Remaja & Dewasa & $\begin{array}{c}\text { Semua } \\
\text { Usia }\end{array}$ \\
\hline 3 & $68,75 \%$ & $38,89 \%$ & $20 \%$ & $60 \%$ \\
\hline 15 & $93,75 \%$ & $34,72 \%$ & $33,33 \%$ & $44.44 \%$ \\
\hline 25 & $93,75 \%$ & $32,89 \%$ & $0 \%$ & $37.5 \%$ \\
\hline 35 & $93,75 \%$ & $32,89 \%$ & $0 \%$ & $42.86 \%$ \\
\hline 45 & $93,75 \%$ & $32,47 \%$ & $0 \%$ & $42.86 \%$ \\
\hline
\end{tabular}

Pada tabel 3 menunjukkan hasil dari precision untuk skenario 1. Dimana dilakukan perhitungan kembali pada k-values selama 5 kali literasi. Skenario 1 menunjukkan dimana, nilai precision tertinggi sebesar 93,75\% yang berada pada kategori anak dengan k 15, 25, 35, dan 45. Sedangkan untuk nilai precision terkecil sebesar $0 \%$ yang berada pada kategori dewasa dengan nilai k 25, 35, dan 45 .

Tabel 4. Hasil Recall Skenario 1

\begin{tabular}{|l|l|l|l|l|}
\hline \multicolumn{5}{|c|}{ Recall } \\
\hline $\mathrm{k}$ & Anak & Remaja & Dewasa & $\begin{array}{c}\text { Semua } \\
\text { Usia }\end{array}$ \\
\hline 3 & $44 \%$ & $84 \%$ & $4 \%$ & $12 \%$ \\
\hline 15 & $60 \%$ & $100 \%$ & $4 \%$ & $16 \%$ \\
\hline 25 & $60 \%$ & $100 \%$ & $0 \%$ & $12 \%$ \\
\hline 35 & $60 \%$ & $100 \%$ & $0 \%$ & $12 \%$ \\
\hline 45 & $60 \%$ & $100 \%$ & $0 \%$ & $12 \%$ \\
\hline
\end{tabular}

Pada tabel 4 menunjukkan hasil dari recall untuk skenario 1. Dimana dilakukan perhitungan kembali pada k-values selama 5 kali literasi. Skenario 1 menunjukkan dimana, nilai recall tertinggi sebesar $100 \%$ yang berada pada kategori remaja dengan $\mathrm{k} 15$, 25, 35, dan 45. Sedangkan nilai recall terendah sebesar $0 \%$ yang berada pada kategori dewasa dengan nilai $\mathrm{k} 25,35$, dan 45 .

Tabel 5. Hasil F-Measure Skenario 1

\begin{tabular}{|c|c|l|l|l|}
\hline \multicolumn{5}{|c|}{ F-Measure } \\
\hline $\mathrm{k}$ & Anak & Remaja & Dewasa & $\begin{array}{c}\text { Semua } \\
\text { Usia }\end{array}$ \\
\hline 3 & $53,66 \%$ & $53,16 \%$ & $6,67 \%$ & $20 \%$ \\
\hline 15 & $73,17 \%$ & $51,55 \%$ & $7,14 \%$ & $23,53 \%$ \\
\hline 25 & $73,17 \%$ & $49,51 \%$ & $0 \%$ & $18,18 \%$ \\
\hline 35 & $73,17 \%$ & $49,51 \%$ & $0 \%$ & $18,75 \%$ \\
\hline 45 & $73,17 \%$ & $49,02 \%$ & $0 \%$ & $18,75 \%$ \\
\hline
\end{tabular}

Pada tabel 5 menunjukkan hasil dari f-measure untuk skenario 1. Dimana dilakukan perhitungan kembali pada $\mathrm{k}$ selama 5 kali literasi. Skenario 1 menunjukkan dimana, nilai f-measure tertinggi sebesar $73.17 \%$ yang berada pada kategori anak dengan $\mathrm{k} 15,25,35$, dan 45 . Sedangkan nilai $f$ measure terendah sebesar $0 \%$ yang berada pada kategori dewasa dengan k 25, 35, dan 45.

Tabel 6. Hasil Akurasi Skenario 1

\begin{tabular}{|c|c|}
\hline $\mathrm{k}$ & Akurasi \\
\hline 3 & $36 \%$ \\
\hline 15 & $45 \%$ \\
\hline 25 & $43 \%$ \\
\hline 35 & $43 \%$ \\
\hline 45 & $43 \%$ \\
\hline
\end{tabular}

Pada tabel 6 menunjukkan hasil dari nilai akurasi yang tertinggi sebesar $45 \%$ ketika dilakukan proses pada $k$-values 15 .

\subsection{Skenario 2}

Pengujian pada skenario 2 dilakukan dengan menggunakan data latih sejumlah 300 dokumen dari pembagian dataset 1,2 , dan 4 dimana pada setiap kategori memiliki jumlah data latih yang sama yaitu sebesar 75, serta menggunakan id dokumen lirik dari id 50 hingga id lirik 75 pada data uji.

Tabel 7. Hasil Precision Skenario 2

\begin{tabular}{|l|l|l|l|l|}
\hline \multicolumn{5}{|c|}{ Precision } \\
\hline $\mathrm{k}$ & Anak & Remaja & Dewasa & $\begin{array}{c}\text { Semua } \\
\text { Usia }\end{array}$ \\
\hline 3 & $68 \%$ & $41,51 \%$ & $66,67 \%$ & $42,86 \%$ \\
\hline 15 & $94,74 \%$ & $36,23 \%$ & $100 \%$ & $60 \%$ \\
\hline 25 & $94,12 \%$ & $34,25 \%$ & $50 \%$ & $66,67 \%$ \\
\hline 35 & $94,12 \%$ & $33,78 \%$ & $66,67 \%$ & $66,67 \%$ \\
\hline 45 & $93,75 \%$ & $32,47 \%$ & $66,67 \%$ & $75 \%$ \\
\hline
\end{tabular}

Pada tabel 7 menunjukkan hasil dari precision untuk skenario 2. Dimana dilakukan perhitungan kembali pada $\mathrm{k}$ selama 5 kali literasi. Skenario 2 
menunjukkan dimana, nilai precision tertinggi sebesar $100 \%$ yang berada pada kategori dewasa dengan $\mathrm{k} 15$. Sedangkan untuk nilai precision terendah sebesar $32.47 \%$ yang berada pada kategori remaja dengan $\mathrm{k} 45$.

Tabel 8. Hasil Recall Skenario 2

\begin{tabular}{|c|l|l|l|l|}
\hline \multicolumn{5}{|c|}{ Recall } \\
\hline $\mathrm{k}$ & Anak & Remaja & Dewasa & $\begin{array}{c}\text { Semua } \\
\text { Usia }\end{array}$ \\
\hline 3 & $68 \%$ & $88 \%$ & $8 \%$ & $12 \%$ \\
\hline 15 & $72 \%$ & $100 \%$ & $8 \%$ & $24 \%$ \\
\hline 25 & $64 \%$ & $100 \%$ & $8 \%$ & $16 \%$ \\
\hline 35 & $64 \%$ & $100 \%$ & $8 \%$ & $16 \%$ \\
\hline 45 & $64 \%$ & $100 \%$ & $8 \%$ & $16 \%$ \\
\hline
\end{tabular}

Pada tabel 8 menunjukkan hasil dari recall untuk skenario 2. Dimana dilakukan perhitungan kembali pada k selama 5 kali literasi. Skenario 2 menunjukkan dimana, nilai recall tertinggi sebesar $100 \%$ yang berada pada kategori remaja dengan $\mathrm{k} 15,25,35$, dan 45. Sedangkan nilai recall terendah adalah sebesar 8 $\%$ yang berada pada kategori dewasa dengan nilai $\mathrm{k}$ $3,15,25,35$, dan 45 .

Tabel 9. Hasil F-Measure Skenario 2

\begin{tabular}{|c|c|c|c|c|}
\hline \multicolumn{5}{|c|}{ F-Measure } \\
\hline $\mathrm{k}$ & Anak & Remaja & Dewasa & $\begin{array}{c}\text { Semua } \\
\text { Usia }\end{array}$ \\
\hline 3 & $68 \%$ & $56,41 \%$ & $14,29 \%$ & $18,75 \%$ \\
\hline 15 & $81,82 \%$ & $53,19 \%$ & $14,81 \%$ & $34,29 \%$ \\
\hline 25 & $76,19 \%$ & $51,02 \%$ & $13,79 \%$ & $25,81 \%$ \\
\hline 35 & $76,19 \%$ & $50,51 \%$ & $14,29 \%$ & $25,81 \%$ \\
\hline 45 & $73,17 \%$ & $49,02 \%$ & $14,29 \%$ & $20,69 \%$ \\
\hline
\end{tabular}

Pada tabel 9 menunjukkan hasil dari f-measure untuk skenario 2. Dimana dilakukan perhitungan kembali pada k selama 5 kali literasi. Skenario 2 menunjukkan dimana, nilai f-measure tertinggi adalah sebesar $81.82 \%$ yang berada pada kategori anak dengan nilai k 15 . Sedangkan nilai $f$-measure terendah adalah sebesar $13.79 \%$ yang berada pada kategori dewasa dengan nilai k 25.

Tabel 10. Hasil Akurasi Skenario 2

\begin{tabular}{|c|c|}
\hline $\mathrm{k}$ & Akurasi \\
\hline 3 & $44 \%$ \\
\hline 15 & $51 \%$ \\
\hline 25 & $47 \%$ \\
\hline 35 & $47 \%$ \\
\hline 45 & $43 \%$ \\
\hline
\end{tabular}

Pada tabel 10 menunjukkan hasil dari nilai akurasi yang tertinggi adalah sebesar $51 \%$ pada nilai $\mathrm{k} 15$.

\subsection{Skenario 3}

Pengujian pada skenario 3 dilakukan dengan menggunakan data latih sejumlah 300 dokumen dari pembagian dataset 1,3 , dan 4 dimana pada setiap kategori memiliki jumlah data latih yang sama yaitu sebesar 75, serta menggunakan id dokumen lirik dari id 25 hingga id lirik 50 pada data uji.

Tabel 11. Hasil Precision Skenario 3

\begin{tabular}{|l|l|l|l|l|}
\hline \multicolumn{5}{|c|}{ Precision } \\
\hline $\mathrm{k}$ & Anak & Remaja & Dewasa & $\begin{array}{c}\text { Semua } \\
\text { Usia }\end{array}$ \\
\hline 3 & $60 \%$ & $37,93 \%$ & $100 \%$ & $30 \%$ \\
\hline 15 & $73,33 \%$ & $33,8 \%$ & $66,67 \%$ & $37,5 \%$ \\
\hline 25 & $84,62 \%$ & $33,33 \%$ & $75 \%$ & $50 \%$ \\
\hline 35 & $91,67 \%$ & $32,89 \%$ & $75 \%$ & $37,5 \%$ \\
\hline 45 & $100 \%$ & $32,47 \%$ & $75 \%$ & $50 \%$ \\
\hline
\end{tabular}

Pada tabel 11 menunjukkan hasil dari precision untuk skenario 3. Dimana dilakukan perhitungan kembali pada k selama 5 kali literasi. Skenario 3 menunjukkan dimana, nilai precision tertinggi adalah sebesar $100 \%$ pada kategori dewasa dengan k 3 dan pada kategori anak dengan k 45. Sedangkan nilai precision terendah adalah sebesar $30 \%$ pada kategori semua usia dengan nilai $\mathrm{k} 3$.

Tabel 12. Hasil Recall Skenario 3

\begin{tabular}{|l|l|l|l|l|}
\hline \multicolumn{5}{|c|}{ Recall } \\
\hline $\mathrm{k}$ & Anak & Remaja & Dewasa & $\begin{array}{c}\text { Semua } \\
\text { Usia }\end{array}$ \\
\hline 3 & $36 \%$ & $88 \%$ & $8 \%$ & $12 \%$ \\
\hline 15 & $44 \%$ & $96 \%$ & $16 \%$ & $12 \%$ \\
\hline 25 & $44 \%$ & $100 \%$ & $12 \%$ & $16 \%$ \\
\hline 35 & $44 \%$ & $100 \%$ & $12 \%$ & $12 \%$ \\
\hline 45 & $44 \%$ & $100 \%$ & $12 \%$ & $16 \%$ \\
\hline
\end{tabular}

Pada tabel 12 menunjukkan hasil dari recall untuk skenario 3. Dimana dilakukan perhitungan kembali pada k selama 5 kali literasi. Skenario 3 menunjukkan dimana, nilai recall tertinggi adalah sebesar $100 \%$ yang berada pada kategori remaja dengan nilai k 25, 35, dan 45. Sedangkan nilai recall terendah adalah sebesar $8 \%$ yang berada pada kategori dewasa dengan nilai $\mathrm{k} 3$.

Tabel 13. Hasil F-Measure Skenario 3

\begin{tabular}{|l|l|l|l|c|}
\hline \multicolumn{5}{|c|}{ F-Measure } \\
\hline $\mathrm{k}$ & Anak & Remaja & Dewasa & $\begin{array}{c}\text { Semua } \\
\text { Usia }\end{array}$ \\
\hline 3 & $68 \%$ & $56,41 \%$ & $14,29 \%$ & $18,75 \%$ \\
\hline 15 & $81,82 \%$ & $53,19 \%$ & $14,81 \%$ & $34,29 \%$ \\
\hline 25 & $76,19 \%$ & $51,02 \%$ & $13,79 \%$ & $25,81 \%$ \\
\hline 35 & $76,19 \%$ & $50,51 \%$ & $14,29 \%$ & $25,81 \%$ \\
\hline 45 & $73,17 \%$ & $49,02 \%$ & $14,29 \%$ & $20,69 \%$ \\
\hline
\end{tabular}


Pada tabel 13 menunjukkan hasil dari $f$-measure untuk skenario 3. Dimana dilakukan perhitungan kembali pada $\mathrm{k}$ selama 5 kali literasi. Skenario 3 menunjukkan dimana, nilai $f$-measure tertinggi adalah sebesar $61.11 \%$ yang berada pada kategori anak dengan nilai k sebesar 45 . Sedangkan nilai $f$ measure terendah adalah sebesar $14.81 \%$ pada kategori dewasa dengan nilai $\mathrm{k} 3$.

Tabel 14. Hasil Akurasi Skenario 3

\begin{tabular}{|c|l|}
\hline $\mathrm{k}$ & Akurasi \\
\hline 3 & $36 \%$ \\
\hline 15 & $42 \%$ \\
\hline 25 & $43 \%$ \\
\hline 35 & $42 \%$ \\
\hline 45 & $43 \%$ \\
\hline
\end{tabular}

Pada tabel 14 menunjukkan hasil dari nilai akurasi tertinggi adalah sebesar $43 \%$ pada k 25 dan 45 .

\subsection{Skenario 4}

Pengujian pada skenario 4 dilakukan dengan menggunakan data latih sejumlah 300 dokumen dari pembagian dataset 2,3 , dan 4 dimana pada setiap kategori memiliki jumlah data latih yang sama yaitu sebesar 75, serta menggunakan id dokumen lirik dari id 1 hingga id lirik 25 pada data uji.

Tabel 15. Hasil Precision Skenario 4

\begin{tabular}{|c|c|c|l|l|}
\hline \multicolumn{5}{|c|}{ Precision } \\
\hline $\mathrm{k}$ & Anak & Remaja & Dewasa & $\begin{array}{c}\text { Semua } \\
\text { Usia }\end{array}$ \\
\hline 3 & $73,33 \%$ & $39,62 \%$ & $25 \%$ & $16,67 \%$ \\
\hline 15 & $81,25 \%$ & $33,78 \%$ & $42,86 \%$ & $33,33 \%$ \\
\hline 25 & $81,25 \%$ & $33,78 \%$ & $50 \%$ & $25 \%$ \\
\hline 35 & $85,71 \%$ & $32,89 \%$ & $50 \%$ & $33,33 \%$ \\
\hline 45 & $80 \%$ & $32,89 \%$ & $40 \%$ & $25 \%$ \\
\hline
\end{tabular}

Pada tabel 15 menunjukkan hasil dari precision untuk skenario 4. Dimana dilakukan perhitungan kembali pada k selama 5 kali literasi. Skenario 4 menunjukkan dimana, nilai precision tertinggi adalah sebesar $85.71 \%$ yang berada pada kategori anak dengan nilai k 35 . Sedangkan untuk nilai precision terendah adalah sebesar $16.67 \%$ pada kategori semua usia dengan nilai $\mathrm{k} 3$.

Pada tabel 16 menunjukkan hasil dari recall untuk skenario 4. Dimana dilakukan perhitungan kembali pada k-values selama 5 kali literasi. Skenario 4 menunjukkan dimana, nilai recall tertinggi adalah sebesar $100 \%$ yang berada pada kategori remaja dengan nilai $\mathrm{k} 15,25,35$, dan 45 . Sedangkan nilai recall terendah adalah sebesar $4 \%$ yang berada pada kategori semua usia dengan nilai k 3, 15, 25, dan 45 . Serta pada kategori dewasa dengan nilai k 3 .
Tabel 16. Hasil Recall Skenario 4

\begin{tabular}{|l|l|l|l|l|}
\hline \multicolumn{5}{|c|}{ Recall } \\
\hline $\mathrm{k}$ & Anak & Remaja & Dewasa & $\begin{array}{c}\text { Semua } \\
\text { Usia }\end{array}$ \\
\hline 3 & $44 \%$ & $84 \%$ & $4 \%$ & $4 \%$ \\
\hline 15 & $52 \%$ & $100 \%$ & $12 \%$ & $4 \%$ \\
\hline 25 & $52 \%$ & $100 \%$ & $12 \%$ & $4 \%$ \\
\hline 35 & $48 \%$ & $100 \%$ & $8 \%$ & $8 \%$ \\
\hline 45 & $48 \%$ & $100 \%$ & $8 \%$ & $4 \%$ \\
\hline
\end{tabular}

Tabel 17. Hasil F-Measure Skenario 4

\begin{tabular}{|c|l|l|l|l|}
\hline \multicolumn{5}{|c|}{ F-Measure } \\
\hline $\mathrm{k}$ & Anak & Remaja & Dewasa & $\begin{array}{c}\text { Semua } \\
\text { Usia }\end{array}$ \\
\hline 3 & $55 \%$ & $53,85 \%$ & $6,9 \%$ & $6,45 \%$ \\
\hline 15 & $63,41 \%$ & $50,51 \%$ & $18,75 \%$ & $7,14 \%$ \\
\hline 25 & $63,41 \%$ & $50,51 \%$ & $19,35 \%$ & $6,9 \%$ \\
\hline 35 & $61,54 \%$ & $49,51 \%$ & $13,79 \%$ & $12,9 \%$ \\
\hline 45 & $60 \%$ & $49,51 \%$ & $13,33 \%$ & $6,9 \%$ \\
\hline
\end{tabular}

Pada tabel 17 menunjukkan hasil dari $f$-measure untuk skenario 4. Dimana dilakukan perhitungan kembali pada k selama 5 kali literasi. Skenario 4 menunjukkan dimana, nilai f-measure tertinggi adalah sebesar $63.41 \%$ yang berada pada kategori anak dengan nilai $\mathrm{k} 15$, dan 25 . Sedangkan untuk nilai $f$-measure terendah adalah sebesar $6.9 \%$ yang berada pada kategori dewasa dengan nilai $\mathrm{k} 3$ dan berada pada kategori semua usia dengan nilai $\mathrm{k} 45$.

Tabel 18. Hasil Akurasi Skenario 4

\begin{tabular}{|c|c|}
\hline $\mathrm{k}$ & Akurasi \\
\hline 3 & $34 \%$ \\
\hline 15 & $42 \%$ \\
\hline 25 & $42 \%$ \\
\hline 35 & $41 \%$ \\
\hline 45 & $40 \%$ \\
\hline
\end{tabular}

Pada tabel 18 menunjukkan hasil dari nilai akurasi tertinggi adalah sebesar $42 \%$ yang berada pada nilai k 15 dan 25 .

\subsection{Analisis Hasil Pengujian}

Dari hasil pengujian yang dilakukan untuk setiap skenario pengujian yang digunakan, dapat diketahui bahwa beberapa faktor yang dapat memberikan pengaruh terhadap keakuratan hasil klasifikasi yang dilakukan dengan menggunakan metode Improved $K$ $N N$. Berdasarkan evaluasi yang yang dilakukan, dapat diketahui bahwa nilai $\mathrm{k}$ yang berbeda yang digunakan, mempengaruhi hasil dari precision, recall, dan $f$-measure.

Hasil pengujian dari Improved $K-N N$ dari beberapa skenario menunjukkan, nilai akurasi tertinggi ada pada $\mathrm{k}$ dengan nilai 15 pada skenario 2 
yakni sebesar $51 \%$ dan terendah ada pada k 3 pada skenario 4 yakni sebesar 34\%. Untuk nilai precision tertinggi ada pada $\mathrm{k} 15$ pada kategori dewasa skenario 2 dan $\mathrm{k} 3$ pada kategori dewasa skenario 3 sebesar masing-masing $10 \%$, sedangkan untuk nilai precision terendah ada pada $\mathrm{k} 25,35$, dan 45 pada kategori dewasa skenario 1 sebesar masing-masing $0 \%$. Untuk nilai recall tertinggi ada pada $\mathrm{k} 15,25,35$, dan 45 pada kategori remaja skenario 2 sebesar $100 \%$ dan kvalues 25,35 , dan 45 pada kategori remaja skenario 3 dan 4 sebesar masing-masing $100 \%$, sedangkan untuk nilai recall terendah ada pada $\mathrm{k} 25,35$, dan 45 pada kategori dewasa skenario 1 sebesar masing-masing $0 \%$. Kemudian untuk nilai $f$-measure tertinggi ada pada k 15 kategori anak pada skenario 2 sebesar $81.82 \%$, sedangkan untuk nilai terendah ada pada $\mathrm{k}$ 25, 35, dan 45 kategori dewasa pada skenario 1.

Nilai precision, recall, dan f-measure berbeda didapatkan apabila $\mathrm{k}$ awal yang digunakan terlalu kecil misal 3 seperti yang ditunjukkan oleh hasil setiap skenario yang mengakibatkan terjadinya kesalahan pada hasil pengklasifikasian. Hasil ini membuktikan bahwa diperlukan ketelitian dalam menentukan $\mathrm{k}$ awal yang terbaik sehingga dapat menghasilkan hasil kategori yang tepat.

\section{Kesimpulan dan Saran}

Adapun kesimpulan yang didapat setelah melakukan penelitian ini adalah Sistem Klasifikasi lirik lagu bahasa Indonesia ini mampu mengkategorikan lirik berdasarkan usianya. Hasil Pengujian menghasilkan akurasi terbaik sebesar 51\%, precision $100 \%$, recall $100 \%$, dan $f$-measure sebesar $100 \%$. Sistem Klasifikasi ini mampu menampilkan lagu berdasarkan rentang usia pendengar.

Adapun saran yang dapat dikembangkan setelah melakukan pengujian skripsi adalah Melakukan pengecekan kembali terhadap sinonim pada kata serta kemiripan kata yang mempunyai makna katanya akan membantu untuk mendapatkan hasil yang lebih maksimal. Pengembangan sistem dengan menggunakan metode yang lain atau menggunakan metode Improved $K-N N$ yang digabungkan dengan metode lain akan mampu memberikan hasil pengklasifikasn yang lebih optimal.

\section{Daftar Pustaka:}

R. Feldman and J. Sanger, (2007): Text Mining Handbook. Cambridge University Press.

N. Muslimah and R. C. Wihandika, (2018): "Klasifikasi Film Berdasarkan Sinopsis dengan Menggunakan Improved K-Nearest Neighbor (K-NN),” J. Pengemb. Teknol. Inf. dan Ilmu Komput. Univ. Brawijaya, vol. 3, no. 1, pp. 196204.

R. D. Nurfarida and R. S. Perdana, (2018): "Klasifikasi Kemacetan Lalu Lintas di Kota Malang Pada Sosial Media Twitter
Menggunakan Metode Improved K-Nearest Neighbor," vol. 3, no. 2, pp. 8823-8830.

L. Baoli, Y. Shiwen, and L. Qin, (2003): "An Improved k -Nearest Neighbor Algorithm."

G. Megantara, A. P. Kurniati, A. A. Suryani, and F. Hasil, (2010): "Klasifikasi teks dengan menggunakan improved k-nearest neighbor algorithm".

A. A. Puspitasari and E. Santoso, (2018): "Klasifikasi Dokumen Tumbuhan Obat Menggunakan Metode Improved k-Nearest Neighbor," vol. 2, no. 2, pp. 486-492.

Thirafi, S.F.M., Rahutomo, F. (2018): "Implementation of Naïve Bayes Classifier Algorithm to Categorize Indonesian Song Lyrics Based on Age", International Conference on Sustainable Information Engineering And Technology (SIET), Malang, Indonesia, pp. 106109.

Rahutomo, Faisal, Thirafi, S.F.M., (2019): "Indonesian song lyrics", Mendeley Data, V2, doi: 10.17632/jsd8rfdgch.2

Hardiyanto, Erik., Rahutomo, Faisal., dan Puspitasari D., (2016): Implementasi K-Nearest Neighbor (KNN) Pada Klasifikasi Artikel Wikipedia Indonesia, Seminar Informatika Aplikatif Polinema (SIAP 2016)

F. Rahutomo, Z. Hanif, R. Adi, and I. F. Rozi, (2018): "Implementasi Text Mining Pada Laman Blog," pp. 101-109.

Rahutomo, Faisal., Pratiwi, Risca Y.I., dan Ramahdani, Mayangsari D., (2019): Eksperimen Naive Bayes Pada Deteksi Berita Hoax Berbahasa Indonesia, Jurnal Penelitian Komunikasi dan Opini Publik Vol.

Herdiawan, (2015): Analisis Sentimen Terhadap Telkom Indihome Berdasarkan Opini Publik Menggunakan Metode Improved K-Nearest Neighbor. 